\title{
Editorial
}

\section{A imagem em campo}

A prática de esportes é, sem dúvida, um dos maiores bens para o ser humano. Nelson Mandela, o mais importante líder sul-africano do século XX, chegou a afirmar que "o esporte tem a força de mudar o mundo". Porém, para aproveitar o máximo da potencialidade do esporte para o indivíduo e para sociedade é preciso conhecê-lo, pesquisá-lo. Nesse sentido, dedicamos o dossiê temático desta edição da revista Discursos Fotográficos para apresentar alguns estudos científicos voltados para compreender as relações entre Imagem e Esporte.

No Brasil, o futebol é considerado o esporte mais popular. Isso explica porque a seleção brasileira de futebol foi tema de dois artigos, mesmo que o contexto das análises tenha tratado de duas situações de derrota. O primeiro deles analisou o processo de articulação de sentidos da fotografia de Reginaldo Manente, vencedora do "Prêmio Esso" de 1982, que trazia a imagem de um menino chorando após derrota do Brasil para a Itália na Copa do Mundo de 1982; a imagem é uma verdadeira narrativa jornalística do sentimento nacional ante àquela derrota esportiva. O outro artigo aborda a cobertura da derrota do Brasil para a Alemanha na Copa do Mundo de 2014; por meio da análise do discurso, o autor busca em quatro imagens publicadas na imprensa brasileira revelar o significada das lágrimas nas narrativas do fotojornalismo esportivo. Ainda no campo do futebol, a experiência do clube-empresa Roma Esporte Apucarana é analisada a partir de um estudo sobre a intencionalidade comunicativa no fotojornalismo do jornal Tribuna do Norte de Apucarana. O último artigo do dossiê apresenta uma análise de fotografias da série especial "Microcosmo", da editoria de esportes da versão digital do jornal Folha de S. Paulo, sobre os Jogos Olímpicos do Rio de Janeiro em 2016; o autor procura investigar como o didatismo e a polissemia derivados do referido 
material fotográfico contribui na construção de um discurso jornalístico.

Esta edição apresenta ainda outras reflexões e pesquisas no campo da comunicação visual que compõem a seção "Artigos". A fotografia é o objeto estudado em dois artigos. Em um deles, o que se propõe é analisar a fotografia como técnica e objeto de estudo na pesquisa qualitativa em Ciências Sociais, destacando-a como instrumento do pesquisador para entender os significados engendrados pelas imagens, suas formas de produção e mediação de sentidos. No outro artigo, a fotografia de Joachim Schmid é analisada a partir dos processos de produção e fruição de sua obra, refletindo sobre a adaptação da arte aos novos panoramas tecnológicos e que nos leva a concluir que é precisamente pela aceitação e integração ao advento da revolução digital que a arte fotográfica saberá encontrar uma sólida forma de se reinventar e de sobreviver. $\mathrm{O}$ cinema também ocupa espaço nesta edição. Em um dos artigos, o filme "O Diabo veste Prada" é analisado sob a perspectiva da Análise do Discurso Francesa com o objetivo de estabelecer a decupagem e a montagem cinematográfica como ferramentas discursivas. Outro artigo aborda a questão da imersão do espectador no cinema com o desenvolvimento do VRCinema; a partir de uma análise histórica do cinema e também dos elementos que configuram o que é chamado pelo autor de "triângulo imersivo" (tela, formato e público), a aplicação da realidade virtual no âmbito cinematográfico é problematizada na medida em que no VRCinema ocorre uma imersão cognoscitiva e física promovida pela dupla apropriação espacial, do real e do virtual. As transformações e inovações do design gráfico punk no seriado infantojuvenil "Peter Punk" do canal Disney XD foi objeto de análise de um dos artigos dessa edição; apesar de constatar importantes mudanças, o autor reconhece a qualidade da obra e considera que as inovações aplicadas a partir de recursos tecnológicos tornaram o estilo gráfico do seriado coerente com o público a que se destina. Por fim, o último artigo da seção "Artigos" traz como tema a Revista 
Illustrada (publicação que circulou no Brasil no último quartel do século XIX) e como objetivo analisar a contribuição da referida publicação na criação de uma espécie de método de transmissão dos acontecimentos com um novo olhar, a partir da mudança dos hábitos e dos referenciais de higiene corporal, de boa educação e de civilidade, principalmente, com o advento da República.

Esta edição traz também uma resenha do livro "A Fotografia na Academia: de formadora de imaginários coletivos a fonte de pesquisas", organizado por Paulo Cesar Boni. Pesquisador de referência na área da fotografia, Boni reuniu vários estudiosos do tema que, de uma forma ou de outra, desenvolveram suas pesquisas a partir de seus vínculos com a Universidade Estadual de Londrina, o que justifica a reivindicação do organizador de que se trata de uma obra que consolida a UEL como vanguarda na pesquisa e ensino da fotografia.

$\mathrm{Na}$ seção "Entrevistas", Márcia Boroski, mestre pelo Programa de Mestrado em Comunicação da Universidade Estadual de Londrina, registra sua conversa com o fotógrafo Gabriel Uchida. Conhecido pelo projeto FotoTorcida, que retrata as grandes torcidas pela perspectiva de dentro (da arquibancada, do ônibus, do caminho até o estádio), Uchida pode ser considerado um expoente da fotografia independente e, nessa entrevista, comenta seu posicionamento político e estético com relação à fotografia, os desafios da área no mercado brasileiro e seus próximos projetos.

Com esta edição, fica o convite para que você pratique o esporte da leitura. 